\title{
Development and validation of a method for the determination of folic acid in different pharmaceutical formulations using derivative spectrophotometry
}

\author{
Marcos Vinícius de Moura Ribeiro, ${ }^{1,2, *}$, Ingrid da Silva Melo², Francisco das Chagas da Costa \\ Lopes$^{2}$, Graziella Ciaramella Moita ${ }^{2}$
}

\author{
${ }^{1}$ Institute of Chemistry, São Paulo State University “Júlio de Mesquita Filho”, UNESP, Araraquara, SP, Brazil, \\ ${ }^{2}$ Department of Chemistry, Natural Science Center, Federal University of Piaui, Teresina, PI, Brazil
}

\begin{abstract}
Folic acid is a B complex water-soluble vitamin that is essential to humans, and its deficiency can cause problems including congenital malformations in the fetus as well as heart disease. Most countries affected by diseases associated with a lack of folic acid now supplement foods with the vitamin. There is therefore a need for the development of new analytical procedures able to determine folic acid present in different matrices. This work describes the development of zero order and first order derivative spectrophotometric methods for the determination of folic acid in different pharmaceutical formulations, using $0.1 \mathrm{~mol} \mathrm{~L}^{-1}$ $\mathrm{NaOH}$ as solvent. The methods are shown to be simple, selective, and robust. Good linearity was achieved, with correction coefficients $\geq 0.9996$ and limits of detection and quantification ranging from 0.64 to 0.75 and from 1.80 to $2.85 \mathrm{mg} \mathrm{L}^{-1}$, respectively. Recoveries of $98-104 \%$ were obtained in accuracy tests, and precision (as RSD) was between 0.2 and $4.8 \%$. The methods can be used in routine analyses for quality control purposes, offering an alternative to the procedures already reported in the literature.
\end{abstract}

Uniterms: Folic acid/pharmaceutical formulations. Folic acid/pharmaceutical formulations/validation method. Folic acid/formulations/derivative spectrophotometry.

\section{INTRODUCTION}

Vitamins are a group of compounds essential for the normal development and growth of living beings. Folic acid (FA) and folates, which are different chemical forms of vitamin $\mathrm{B}_{9}$, belong to the water-soluble B-group vitamins (Zare, Shishehbore, Nematollahi, 2011; Catharino, Godoy, Lima-Pallone, 2006; Nasser et al., 2005). Folate is a generic term for compounds possessing vitamin activity similar to that of pteroylglutamic acid, and is the form of the vitamin naturally present in foods (Krishnaswamy, Nair, 2001). Folic acid is a synthetic form of folate, found in vitamin supplements and fortified foods (Bailey, 2000). The main dietary sources of folic acid are spinach, white beans, asparagus, dark-leaved vegetables, Brussels sprouts, soybean and its derivatives, oranges, and melons, amongst others (Nasser et al., 2005; Deconinck

\footnotetext{
*Correspondence: M. V. M. Ribeiro. Instituto de Química. Universidade Estadual Paulista - UNESP. Rua Prof. Francisco Degni 55 - Jardim Quitandinha 14800-060 - Araraquara - SP, Brasil. E-mail: marcosvinicius1703@hotmail.com
}

et al., 2011). An important feature of vitamins is that they are generally not synthesized by mammalian cells and must therefore be supplied in sufficient amounts in the diet (Aurora-Prado et al., 2004).

At present, vitamin deficiency results mainly from poverty, food preferences, drug use, and chronic alcoholism, amongst other causes. If vitamin intake is insufficient, multivitamin preparations can be used in order to prevent vitamin deficiency and the associated physiological problems (Deconinck et al., 2011; AuroraPrado et al., 2004).

The chemical name of FA is $N$-[4-[[(2-amino-3,4dihydro-4-oxo-6-pteridinyl)methyl]amino]benzoyl]L-glutamic acid (Deconinck et al., 2011; Flores et al., 2005; Nagaraja, Vasantha, Yathirajan, 2002). Its structure is shown in Figure 1. It is essential for the formation of red blood cells and is important for growth and the prevention of anemia (Zhao et al., 2006). FA deficiency can lead to congenital malformations in the fetus (spina bifida, encephalocele, cleft palate, and hydrocephalus), as well as heart disease (Crane et al., 1995; Czeize, 
Dudas, 1992; Oakley, Erickson, Adams, 1995; Santos, Pereira, 2007).<smiles>Nc1nc(O)c2nc(CNc3ccc(C(=O)N[C@@H](CCC(=O)O)C(=O)O)cc3)cnc2n1</smiles>

FIGURE 1 - Structure of the folic acid molecule.

To date, FA is the most important risk factor identified for neural tube defects (Santos, Pereira, 2007). The severity of these defects means that it is important to undertake genetic counseling, supplement diets with folic acid, and perform prenatal diagnosis of neural tube defects (Pacheco et al., 2009). FA is required for normal growth, reproduction (during gestation and lactation), and antibody formation. It acts as a coenzyme in the metabolism of amino acids (glycine) and the synthesis of purines, pyrimidines, DNA, and RNA, and is vital for cell division and protein synthesis. Its deficiency can alter DNA synthesis and induce chromosomal changes (Santos, Pereira, 2007).

Folic acid is nontoxic, although there is some concern that high doses may mask pernicious anemia. This effect is only likely following ingestion of quantities greater than $5 \mathrm{mg}$. Medicines containing levels of folic acid above the recommended values can be harmful to consumers (Cozzolino, 2009). There is therefore a continuing need for the development of new analytical procedures for the determination of FA present in pharmaceutical formulations (Zhao et al., 2006). In most countries affected by FA deficiency, foods are supplemented with the vitamin (Catharino, Godoy, 2001; Catharino, Visentainer, Godoy, 2003; Caselunghe, Lindeberg, 2000).

According to the Brazilian Pharmacopoeia (ANVISA, 2010), high performance liquid chromatography (HPLC) is recommended for the identification and quantification of FA in pharmaceutical formulations. Although HPLC is a well-established technology in the pharmaceutical field, offering sensitivity and specificity, its disadvantages include high operating costs, the need for large amounts of samples and solvents, and the generation of hazardous wastes such as organic solvents that are expensive to dispose of and can have significant environmental impacts (Deconinck et al., 2011).

Methods reported in the literature for the determination of folic acid include HPLC with different detectors (Aurora-Prado et al., 2004; Nelson, Sharpless, Sander, 2006; Chaudhary, Wang, Prabhu, 2010), electrophoresis (Zhao et al., 2006), electrochemical methods (Vaze, Srivastava, 2007; Prasad et al., 2010; Ensafi, Karimi-Maleh, 2010), flow injection analysis (Nie, $\mathrm{He}, \mathrm{Lu}, 2000$ ), and spectrophotometric methods (Pesce, Bodourian, 1986; Rao, Kanjilal, Mohan, 1978). The use of flow injection analysis and zero order spectrophotometry is problematic for the determination of folic acid in complex samples containing large amounts of interferents, because both techniques require prior extraction of the analyte, hence increasing the costs of routine analysis. However, the use of derivative spectrophotometry offers a simple and inexpensive solution for the determination of drugs in pharmaceutical formulations (Rêgo, Moura, Moita, 2010; Moura, Moita, 2012).

Derivative spectrophotometry has been widely used as a tool for the quality control of medicines, enabling the simultaneous determination of different drugs in multicomponent media. Derivation of the spectra enables the separation of superimposed signals and eliminates the background signal caused by the presence of other species in the sample. This technique can improve sensitivity and selectivity in the analysis of mixtures. Furthermore, it is accessible to most laboratories, since the procedure is simple, fast, and does not require prior extraction of the analyte from the sample (Donato et al., 2010; Vidotti, Rollemberg, 2006).

According to the criteria of the Brazilian National Health Surveillance Agency (ANVISA, 2003), a method must be validated experimentally in order to ensure that it meets the requirements of the analytical applications, hence ensuring the reliability of the results. The parameters considered include specificity, linear range, precision, sensitivity, quantification limit, and accuracy (ICH, 2000; INMETRO, 2011). The objective of the present work was therefore to develop and validate a method for the quantification of folic acid in pharmaceutical formulations by derivative spectrophotometry, comparing the technique to existing methods described in the literature.

\section{MATERIAL AND METHODS}

\section{Reagents}

Standards and pharmaceuticals

A reference standard of folic acid $(99.77 \%)$ was 
obtained from Pharmanostra ${ }^{\circledR}$. Samples of folic acid were studied in the form of tablets $(5 \mathrm{mg})\left(\right.$ Folacin $^{\circledR}$, lot \#12097614), solution (400 mg L-1) $\left(\right.$ Folacin $^{\circledR}$, lot \#1106225), and capsules (5 mg) (lot \#019239). The samples were purchased in drugstores and prescription pharmacies.

Evaluation of interferents employed excipients used in commercial pharmaceutical formulations. These were: lactose $\left(\right.$ Pharmanostra $\left.^{\circledR}\right)$, talc $\left(\right.$ Henrifarma $\left.^{\circledR}\right)$, magnesium stearate (Valdequímica ${ }^{\circledR}$ ), microcrystalline cellulose $\left(\right.$ Pharmanostra $\left.^{\circledR}\right)$, silicon dioxide $\left(\right.$ Henrifarma $\left.^{\circledR}\right)$, titanium dioxide $\left(\right.$ Deg $\left.^{\circledR}\right)$, methylparaben $\left(\right.$ Fagron $\left.^{\circledR}\right)$, propylparaben $\left(\right.$ Pharmanostra $^{\circledR}$ ), and ascorbic acid (Impex).

\section{Reagents}

Evaluation of the solvents used employed three different brands of sodium hydroxide (Synth, 97.0\%; Impex, 99.0\%; and Vetec, 99.0\%), sodium carbonate (Dinâmica, 99.5\%), and hydrochloric acid (Merck, $37.0 \%$ ). The solvent solutions were prepared using deionized water. All reagents used were analytical grade.

\section{Instrumentation and treatment of the data}

The spectrophotometric analyses were performed with a double beam Hitachi U-3000 spectrophotometer fitted with deuterium and tungsten lamps, using a scan range of 190-750 nm, scan speed of $300 \mathrm{~nm} \mathrm{~min}^{-1}$, and slit width of $2.0 \mathrm{~nm}$. Quartz cuvettes with optical path length of $1 \mathrm{~cm}$ were used. The samples were centrifuged using a New Instrument NI 1812 centrifuge. Mass measurements were made with a Denver Instrument APX 200 analytical balance.

Origin 7.5 software (OriginLab) was used for statistical treatment of the data and the construction of graphs. Derivation of the spectra was performed with Hitachi UV00 spectrophotometry software.

\section{Analytical validation}

\section{Robustness}

The robustness of the method was evaluated using the following parameters: stability of the folic acid solutions, brand of sodium hydroxide, and concentration of the solvent.

For evaluation of the stability of the solutions, stock solutions of $100 \mathrm{mg} \mathrm{L}^{-1}$ folic acid were prepared in $0.1 \mathrm{~mol} \mathrm{~L}^{-1}$ sodium hydroxide and $0.27 \mathrm{~mol} \mathrm{~L}^{-1}$ sodium carbonate. The stock solutions were divided into three $250 \mathrm{~mL}$ flasks, one of which was transparent (allowing the passage of light) and the others amber (preventing the entry of light). The solution contained in the transparent bottle was kept on the laboratory bench and was exposed to ambient light during the daytime, and the others were wrapped in aluminum foil. One of the two solutions that were protected from light was kept at an average ambient temperature of $27.0 \pm 4.0^{\circ} \mathrm{C}$, while the other was refrigerated at an average temperature of $3.0 \pm 2.0^{\circ} \mathrm{C}$. For the analyses, the stock solutions were diluted to $10 \mathrm{mg} \mathrm{L}^{-1}$ and spectra were acquired daily during a period of 4 days, and subsequently every 5 days up to 30 days. The analysis of variance (ANOVA, $p=0.05$ ) was used to evaluate the data obtained at the wavelength of maximum absorption, in the range studied, and at a further 14 points located around $\lambda_{\text {max }}$.

The study of different brands of sodium hydroxide was carried out using solutions of $10 \mathrm{mg} \mathrm{L}^{-1}$ folic acid in $0.1 \mathrm{~mol} \mathrm{~L}^{-1}$ solutions of sodium hydroxide obtained from the different manufacturers (Synth, Vetec, and Impex). All spectra were acquired in triplicate and the analysis of variance (ANOVA, $p=0.05$ ) was used to evaluate the data obtained at the wavelength of maximum absorption and at a further 14 points located around $\lambda_{\max }$.

The influence of the solvent concentration was evaluated using solutions of $10 \mathrm{mg} \mathrm{L}^{-1}$ folic acid in different concentrations of sodium hydroxide: $0.05,0.1$, and $0.2 \mathrm{~mol} \mathrm{~L}^{-1}$. All solutions were prepared in triplicate and then submitted to spectrophotometric analysis. The results were evaluated using the analysis of variance (ANOVA, $\mathrm{p}=0.05$ ), as described above.

\section{Linearity}

Analytical curves were constructed using six folic acid concentrations between 5 and $50 \mathrm{mg} \mathrm{L}^{-1}$, prepared from a stock $100 \mathrm{mg} \mathrm{L}^{-1}$ solution. Spectral scanning of the solutions was then performed to obtain the zero order spectra. The $1^{\text {st }}, 2^{\text {nd }}, 3^{\text {rd }}$, and $4^{\text {th }}$ order derivatives of the spectra were obtained, with $\Delta \lambda$ varied between 1 and 10 $\mathrm{nm}$, using the UV00 spectrophotometer software.

\section{Detection and quantification limits}

The limits of detection and quantification were calculated using the expressions LOD $=3 s / a$ and LOQ $=$ $10 s / a$, respectively, where $s$ is the standard deviation of the blank signal and $a$ is the slope (or angular coefficient) of the calibration curve (Moura, Moita, 2012). These calculations were performed using 21 blank spectra.

\section{Selectivity}

The selectivity of the method was assessed by analysis of the spectra of the excipients used in the pharmaceutical products prepared as tablets, capsules, and solution. The excipients were: lactose (50 to $250 \mathrm{mg}$ 
$\mathrm{L}^{-1}$ ), talc (50 to $250 \mathrm{mg} \mathrm{L}^{-1}$ ), magnesium stearate (50 to $250 \mathrm{mg} \mathrm{L}^{-1}$ ), microcrystalline cellulose (50 to $\left.250 \mathrm{mg} \mathrm{L}^{-1}\right)$, silicon dioxide ( 50 to $250 \mathrm{mg} \mathrm{L}^{-1}$ ), titanium dioxide (50 to $\left.150 \mathrm{mg} \mathrm{L}^{-1}\right)$, methylparaben (10 $\left.\mathrm{mg} \mathrm{L}^{-1}\right)$, propylparaben (10 $\left.\mathrm{m} \mathrm{L} \mathrm{L}^{-1}\right)$, and ascorbic acid $\left(100 \mathrm{mg} \mathrm{L}^{-1}\right)$. The spectra obtained were compared with the spectrum of a $10 \mathrm{mg} \mathrm{L}^{-1}$ folic acid standard solution.

\section{Accuracy}

Accuracy was assessed by addition and recovery tests using standards at three concentration levels (50, 100 , and $150 \%$ ). In the case of the Folacin ${ }^{\circledR}$ solution, a $100 \mathrm{mg} \mathrm{L}^{-1}$ standard solution of folic acid was prepared, and $0.5,1.0$, and $1.5 \mathrm{~mL}$ aliquots were transferred to three $10 \mathrm{~mL}$ volumetric flasks. The drug solution was then used to prepare a solution containing $200 \mathrm{mg} \mathrm{L}^{-1}$ of folic acid, and $0.5 \mathrm{~mL}$ aliquots were transferred to the flasks containing the folic acid standard solutions, prepared previously. The volumes were then completed with the solvent, resulting in final concentrations of $0,5.0,10.0$, and $15.0 \mathrm{mg} \mathrm{L}^{-1}$ of folic acid standard and $10 \mathrm{mg} \mathrm{L}^{-1}$ of folic acid from the drug sample. All the procedures were performed in triplicate, using $0.1 \mathrm{~mol} \mathrm{~L}^{-1} \mathrm{NaOH}$ as the solvent.

For the Folacin ${ }^{\circledR}$ tablet product, five tablets were crushed, and masses corresponding to $2.5 \mathrm{mg}$ of folic acid were weighed out and transferred quantitatively to four $25 \mathrm{~mL}$ volumetric flasks, followed by addition of 2.5, 5.0, and $7.5 \mathrm{~mL}$ aliquots of a $500 \mathrm{mg} \mathrm{L}^{-1}$ folic acid standard solution. The volumes were then completed with the solvent, and the samples were centrifuged for $30 \mathrm{~min}$ at $3500 \mathrm{rpm}$, and then filtered with a quantitative filter paper to remove suspended material. Finally, $1 \mathrm{~mL}$ aliquots of each solution were transferred to $10 \mathrm{~mL}$ volumetric flasks and the volumes were completed with $0.1 \mathrm{~mol} \mathrm{~L}^{-1} \mathrm{NaOH}$ to give final concentrations of $0,5.0,10.0$, and $15.0 \mathrm{mg} \mathrm{L}^{-1}$ of standard and $10 \mathrm{mg} \mathrm{L}^{-1}$ of folic acid from the sample. These solutions were prepared in triplicate, and the accuracy was expressed in terms of the percentage recovery. The same procedure was used for the capsule form of the drug.

\section{Precision}

Evaluation was made of intra-day and inter-day precision. The drug samples were used to prepare 100 $\mathrm{mg} \mathrm{L}^{-1}$ folic acid solutions, in triplicate. In the case of the tablet and capsule samples, the solutions were centrifuged for $30 \mathrm{~min}$ at $3500 \mathrm{rpm}$, and then filtered with quantitative filter paper to remove suspended material. The solutions were diluted to $10 \mathrm{~mL}$ in volumetric flasks to obtain (in triplicate) folic acid concentrations of 15.0, 25.0, and 35.0 $\mathrm{mg} \mathrm{L}^{-1}$. The results obtained were expressed in terms of relative standard deviations (RSD).

\section{RESULTS AND DISCUSSION}

According to the Brazilian Pharmacopoeia (BRASIL, 2010), folic acid is insoluble in water and organic solvents, but exhibits good solubility in hydroxides, carbonates, and hot hydrochloric acid. The literature reports methods using sodium hydroxide and sodium carbonate as solvents, with folic acid showing good solubility under these conditions (Flores et al., 2005; Zhao et al., 2006). This is due to reaction of the bases with the carboxylic groups present in the folic acid structure (Figure 1), resulting in the formation of carboxylic salts that are highly soluble in aqueous media. Under these conditions, the spectrum of the folic acid solution showed three well-defined bands of maximum absorption, at wavelengths of $255.5,283.0$, and $365.5 \mathrm{~nm}$ (Figure 2). In the case of hydrochloric acid, a low intensity band was observed and poor dissolution was achieved using acid concentrations of 1.0 and $3.0 \mathrm{~mol} \mathrm{~L}^{-1}$.

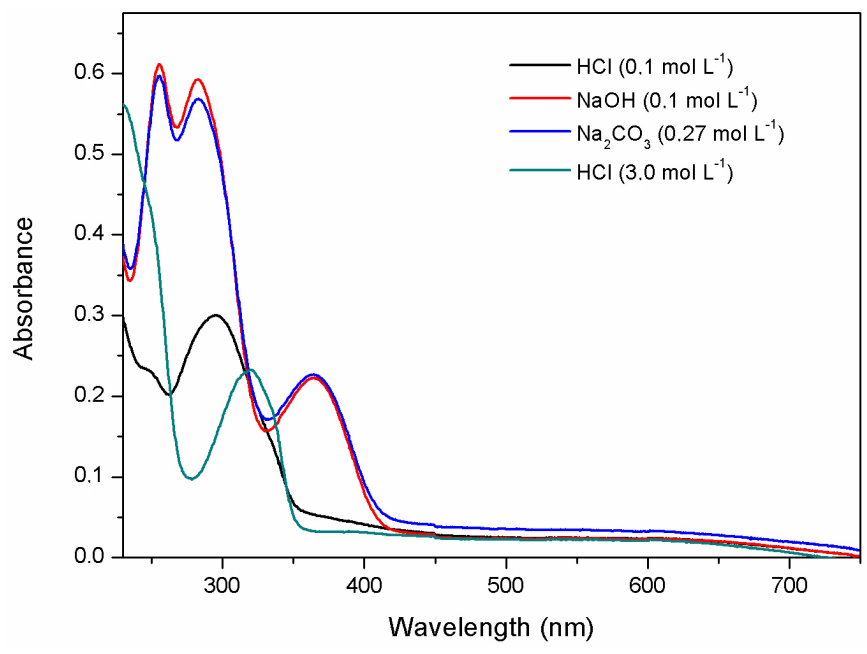

FIGURE 2 - Spectra obtained for $10 \mathrm{mg} \mathrm{L}^{-1}$ folic acid in the presence of different solvents.

\section{Robustness of the method}

Stability

The stability tests showed that in the presence of sodium hydroxide, the standard solution of folic acid was stable for up to 28 days at ambient temperature, in both the presence and absence of light (Figures 3 and 4). The analysis of variance (ANOVA, $p=0.05$ ) performed for the wavelength range around $\lambda_{\text {max }}$ showed that the absorbances were statistically the same during this period. The same behavior was observed for the refrigerated samples.

In the case of the standard solutions of folic acid in the presence of sodium carbonate, there was a marked 
decrease in the absorbance value at a wavelength of $255.5 \mathrm{~nm}$ (Figure 3), which was due to photochemical degradation of the solution in the presence of light. This was also indicated by a progressive change in the color of the standard solution, from light yellow to dark yellow. In the absence of light, the behavior was similar to that observed using sodium hydroxide (Figure 4). These results were in agreement with the findings of other studies using HPLC (Catharino, Godoy, 2001; Catharino, Visentainer, Godoy, 2003). Sodium hydroxide was therefore selected as the solvent in subsequent experiments.

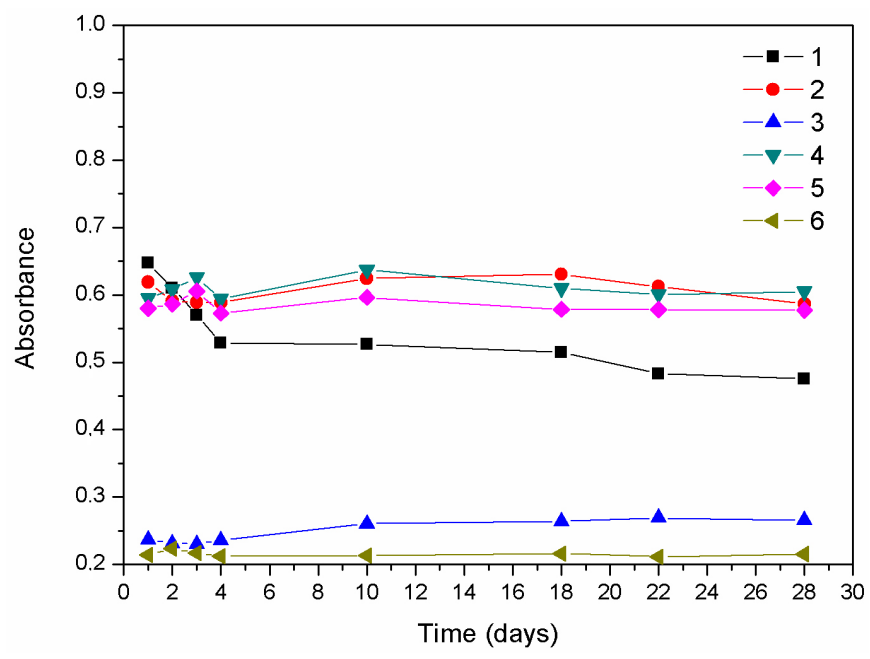

FIGURE 3 - Stability of $10 \mathrm{mg} \mathrm{L}^{-1}$ folic acid solutions in the presence of light, using $0.27 \mathrm{~mol} \mathrm{~L}^{-1} \mathrm{Na}_{2} \mathrm{CO}_{3}$ (255.5 nm (1), $283.0 \mathrm{~nm}(2), 365.5 \mathrm{~nm}(3))$ and $0.1 \mathrm{~mol} \mathrm{~L}^{-1} \mathrm{NaOH}(255.5 \mathrm{~nm}$ (4), $283.0 \mathrm{~nm}(5), 365.5 \mathrm{~nm}(6))$.

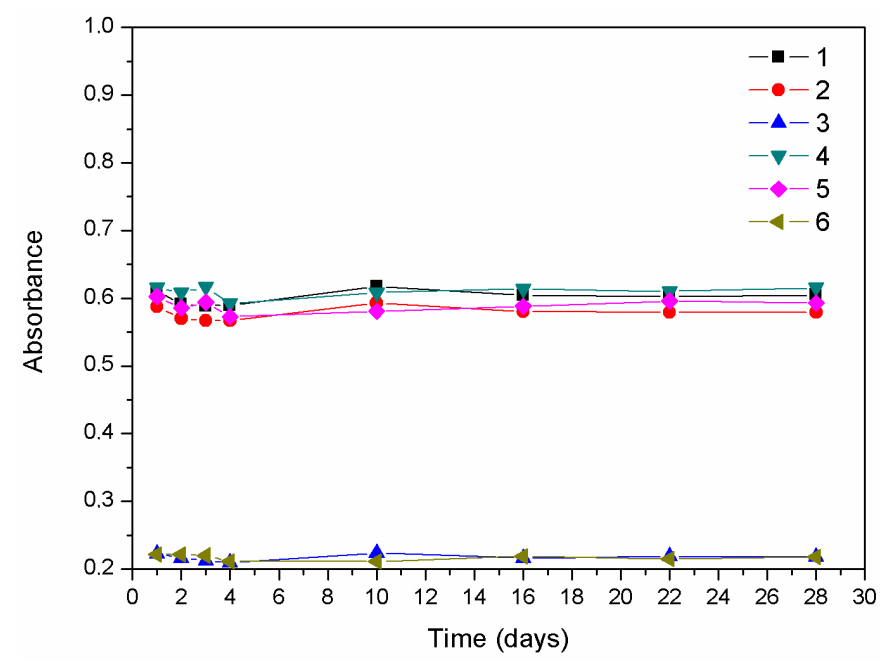

FIGURE 4 - Stability of $10 \mathrm{mg} \mathrm{L}^{-1}$ folic acid solutions in the absence of light, using $0.1 \mathrm{~mol} \mathrm{~L}^{-1} \mathrm{Na}_{2} \mathrm{CO}_{3}$ (255.5 nm (1), $283.0 \mathrm{~nm}(2), 365.5 \mathrm{~nm}(3))$ and $0.1 \mathrm{~mol} \mathrm{~L}^{-1} \mathrm{NaOH}$ (255.5 nm (4), $283.0 \mathrm{~nm}(5), 365.5 \mathrm{~nm}(6))$.

\section{Influence of brand of sodium hydroxide}

Evaluation of the folic acid spectra obtained using the different brands of sodium hydroxide showed that there was no significant difference (paired t-test, $p=0.05$ ) between the measured absorbances for the Impex and Vetec brands, which could be explained by the fact that the degree of purity was $99.0 \%$ in both cases. However, when these spectra were compared with those obtained using sodium hydroxide from Synth, there was a difference in absorbance (ANOVA, $\mathrm{p}=0.05$ ), due to the lower degree of purity $(97.0 \%)$ of the latter.

\section{Influence of solvent concentration}

No significant differences (ANOVA, $\mathrm{p}=0.05$ ) were observed between the folic acid absorbance spectra acquired for the samples with three different concentrations of sodium hydroxide $\left(0.05,0.1\right.$, and $\left.0.2 \mathrm{~mol} \mathrm{~L}^{-1}\right)$. Since folic acid dissolved more rapidly in the presence of a higher concentration of the base, it was decided to use 0.1 mol L-1 sodium hydroxide, which provided good stability of the standard solution and lower consumption of the reagent, compared to use of the $0.2 \mathrm{~mol} \mathrm{~L}^{-1}$ solution.

\section{Evaluation of selectivity}

The excipients used in the preparation of the capsules and tablets showed poor solubility in the solvent used. Talc was easily precipitated, while titanium dioxide and magnesium stearate remained in suspension. At higher concentrations, the turbidity of the suspensions increased, resulting in higher analytical signals throughout the entire spectrum, due to scattering of the radiation. This interference could affect the precision and accuracy of the method, and was therefore avoided using centrifugation and filtration. The excipients were tested at different concentrations, because the manufacturers did not provide any information concerning the quantities used.

In the case of the excipients used in the solution formulation, there was superimposition of the zero order folic acid spectrum and the excipient spectra, because the absorbance maxima of the latter were very close to that of folic acid, which hindered its determination (Figure 5). The zero crossing technique was therefore used to eliminate this interference (Moura, Moita, 2012). The spectra of folic acid and the excipients were evaluated using four derivative orders and ten different $\Delta \lambda$. A significant folic acid signal was only obtained at a wavelength of $393.0 \mathrm{~nm}$ for the first derivative (D1) and for $\Delta \lambda 8, \Delta \lambda 9$, and $\Delta \lambda 10$, with the excipients showing zero signals (Figure 6). 


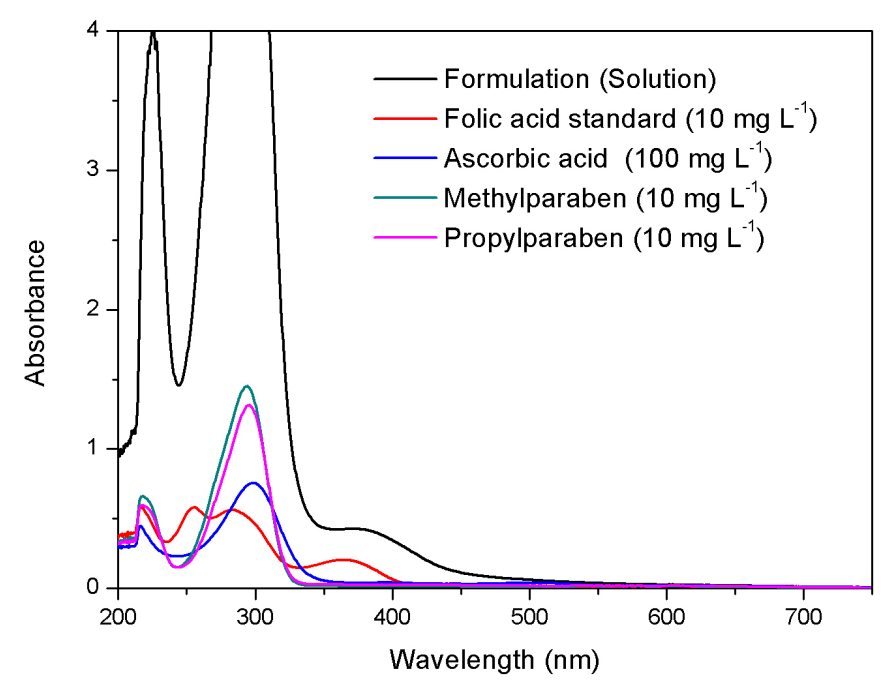

FIGURE 5 - Comparison of zero order spectra for $10 \mathrm{mg} \mathrm{L}^{-1}$ folic acid and the main excipients used in the solution formulation.

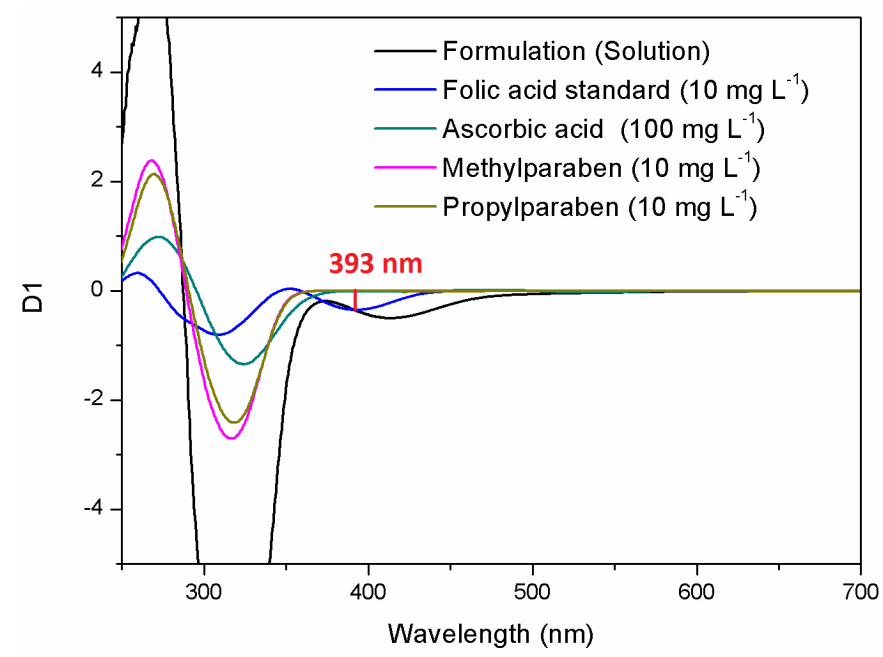

FIGURE 6 - Comparison of $\Delta \lambda 10$ first derivative spectra for $10 \mathrm{mg} \mathrm{L}^{-1}$ folic acid and the main excipients used in the solution formulation.

\section{Linearity and limits of detection and quantification}

Table I shows the parameters of the calibration curves obtained for standard solutions of folic acid in 0.1 mol L-1 sodium hydroxide. The curves presented good slopes, intercepts near zero, and correlation coefficients that exceeded the values recommended by ANVISA (2003) $(\mathrm{r}=0.99)$ and INMETRO $(2011)(\mathrm{r}=0.9)$. The detection and quantification limits were in the ranges $0.64-0.85$ and 1.80-2.85 $\mathrm{mg} \mathrm{L}^{-1}$, respectively, and were lower than the lowest concentration in the solutions analyzed $\left(5 \mathrm{mg} \mathrm{L}^{-1}\right)$. The developed method therefore provided satisfactory sensitivity and linearity. The results were similar to those obtained previously using chromatographic (AuroraPrado et al., 2004; Zhao et al., 2006; Nelson, Sharpless, Sander, 2006) and electrochemical techniques (Zare, Shishehbore, Nematollahi, 2011; Vaze, Srivastava, 2007; Ensafi, Karimi-Maleh, 2010) for the analysis of folic acid in different matrices.

Evaluation was made of differences in the analytical parameters at different $\Delta \lambda$, using the wavelength of 393.0 $\mathrm{nm}$ (D1), since in the case of the Folacin ${ }^{\circledR}$ solution, only the first derivative gave satisfactory results. It can be seen from the data provided in Table I that the results obtained for $\Delta \lambda 10$ were similar to those found for $\Delta \lambda 8$ and $\Delta \lambda 9$, with only slight differences, since the increase of $\Delta \lambda$ provided better signal resolution by decreasing the noise present in the spectrum.

\section{Accuracy of the method}

The results of the accuracy tests (Table II), performed in triplicate using three concentration levels, showed that in most cases the recoveries ranged from 98 to $105 \%$, within the limits established by ANVISA (80-120\%). In

TABLE I - Analytical parameters for the quantification of folic acid

\begin{tabular}{lcccccc}
\hline Method & $\boldsymbol{\lambda}(\mathbf{n m})$ & Linear equation & $\mathbf{r}$ & $\mathbf{L O D}\left(\mathbf{m g ~ \mathbf { L } ^ { - 1 }}\right)$ & $\mathbf{L O Q}\left(\mathbf{m g ~ \mathbf { L } ^ { - 1 }}\right)$ & $\mathbf{L O L}\left(\mathbf{m g ~ \mathbf { L } ^ { - 1 }}\right)$ \\
\hline ZO & 255.5 & $\mathrm{~A}=0.041+0.054 \mathrm{C}$ & 0.9996 & 0.75 & 2.51 & 50 \\
ZO & 283.0 & $\mathrm{~A}=0.035+0.053 \mathrm{C}$ & 0.9996 & 0.81 & 2.71 & 50 \\
ZO & 365.5 & $\mathrm{~A}=0.020+0.019 \mathrm{C}$ & 0.9988 & 0.85 & 2.85 & 50 \\
D1 $(\Delta \lambda 8)$ & 393.0 & $\mathrm{D} 1=-0.004-0.032 \mathrm{C}$ & 0.9998 & 0.67 & 1.80 & 50 \\
D1 $(\Delta \lambda 9)$ & 393.0 & $\mathrm{D} 1=-0.005-0.034 \mathrm{C}$ & 0.9998 & 0.65 & 1.80 & 50 \\
D1 $(\Delta \lambda 10)$ & 393.0 & $\mathrm{D} 1=-0.005-0.035 \mathrm{C}$ & 0.9998 & 0.64 & 1.78 & 50 \\
\hline
\end{tabular}

ZO - Zero order, D1 - First order derivative, LOD - Limit of detection, LOQ - Limit of quantification, LOL - Limit of linearity, $\mathrm{r}$ - linear correlation coefficient. 
tests with the Folacin ${ }^{\circledR}$ solution, the values obtained using the ZO method $(365.5 \mathrm{~nm})$ were in the range $90-94 \%$, with RSD of up to $10.3 \%$, due to the spectral overlap associated with the excipients used in the formulation (Figure 5). This difficulty was resolved using method D1 (393.0 nm) at different $\Delta \lambda$, resulting in recovery values in the range $100-104 \%$ (Table II).

Similar recoveries were obtained in previous studies using HPLC (94.3-105.8\% and $\geq 95 \%$ ) (Zhao et al., 2006; Nelson, Sharpless, Sander, 2006), electrochemical methods (97.7-103.6\%) (Beitollahi, Sheikhshoaie, 2011), and flow injection analysis (>95.3\%) (Nie, He, Lu, 2000).

\section{Precision of the method}

Intra-day and inter-day precisions (Table III) were determined using three concentration levels. The data showed that the method provided high levels of precision when used by the same analyst on the same day and by

TABLE II - Results of accuracy tests for the samples at three concentration levels

\begin{tabular}{|c|c|c|c|c|c|}
\hline Formulation & $\begin{array}{c}\text { Method } \\
(\lambda, \mathrm{nm})\end{array}$ & $\begin{array}{c}\text { Added } \\
\left(\mathrm{mg} \mathrm{L}^{-1}\right)\end{array}$ & $\begin{array}{c}\text { Recovered } \\
\left(\mathrm{mg} \mathrm{L}^{-1}\right)\end{array}$ & $\begin{array}{c}\text { Recovery } \\
(\%)\end{array}$ & $\begin{array}{l}\text { RSD } \\
(\%)\end{array}$ \\
\hline$\overline{\text { Folacin }^{\circledR}}$ & $\mathrm{ZO}$ & 5.0 & 4.5 & 90 & 3.9 \\
\hline \multirow[t]{11}{*}{ (solution) } & $(365.5)$ & 10.0 & 9.4 & 94 & 10.3 \\
\hline & & 15.0 & 13.9 & 92 & 7.2 \\
\hline & D1 & 5.0 & 4.9 & 98 & 3.1 \\
\hline & (393.0) & 10.0 & 10.5 & 105 & 0.5 \\
\hline & $\Delta \lambda 10$ & 15.0 & 15.2 & 101 & 2.0 \\
\hline & D1 & 5.0 & 5.2 & 103 & 2.2 \\
\hline & $(393.0)$ & 10.0 & 10.5 & 105 & 3.2 \\
\hline & $\Delta \lambda 9$ & 15.0 & 15.5 & 103 & 1.9 \\
\hline & $\bar{D} 1$ & 5.0 & 5.0 & 100 & 3.5 \\
\hline & (393.0) & 10.0 & 10.4 & 104 & 3.2 \\
\hline & $\Delta \lambda 8$ & 15.0 & 15.3 & 102 & 2.0 \\
\hline & $\mathrm{ZO}$ & 5.0 & 5.1 & 103 & 4.8 \\
\hline \multirow[t]{11}{*}{ (tablet) } & $(255.5)$ & 10.0 & 10.2 & 102 & 2.4 \\
\hline & & 15.0 & 15.0 & 100 & 1.2 \\
\hline & $\mathrm{ZO}$ & 5.0 & 5.1 & 102 & 4.9 \\
\hline & $(283.0)$ & 10.0 & 10.1 & 101 & 2.5 \\
\hline & & 15.0 & 14.9 & 99 & 1.4 \\
\hline & $\mathrm{ZO}$ & 5.0 & 5.0 & 100 & 5.0 \\
\hline & $(365.5)$ & 10.0 & 10.0 & 100 & 2.6 \\
\hline & & 15.0 & 14.7 & 98 & 2.6 \\
\hline & D1 & 5.0 & 5.1 & 102 & 4.4 \\
\hline & (393.0) & 10.0 & 10.1 & 101 & 1.6 \\
\hline & $\Delta \lambda 10$ & 15.0 & 15.0 & 100 & 0.5 \\
\hline \multirow[t]{12}{*}{ Capsules } & $\mathrm{ZO}$ & 5.0 & 5.1 & 102 & 0.7 \\
\hline & $(255.5)$ & 10.0 & 10.4 & 104 & 1.5 \\
\hline & & 15.0 & 14.7 & 98 & 0.4 \\
\hline & $\mathrm{ZO}$ & 5.0 & 5.0 & 100 & 1.2 \\
\hline & $(283.0)$ & 10.0 & 10.4 & 104 & 1.5 \\
\hline & & 15.0 & 14.7 & 98 & 0.3 \\
\hline & $\mathrm{ZO}$ & 5.0 & 5.0 & 101 & 2.7 \\
\hline & $(365.5)$ & 10.0 & 10.4 & 104 & 1.4 \\
\hline & & 15.0 & 14.8 & 99 & 1.1 \\
\hline & D1 & 5.0 & 5.2 & 104 & 1.2 \\
\hline & (393.0) & 10.0 & 10.4 & 104 & 1.0 \\
\hline & $\Delta \lambda 10$ & 15.0 & 14.7 & 98 & 0.9 \\
\hline
\end{tabular}


different analysts on different days, with RSD values ranging from 0.2 to $4.8 \%$, which were lower than the maximum allowed by ANVISA (5.0\%). The lowest values were found for method D1 $(393.0 \mathrm{~nm})$, showing that use of the derivative improved the signal and eliminated interference.

The intra- and inter-day precisions were assessed by application of the F-test and the paired t-test $(\mathrm{p}=0.05)$. The results revealed that for the three concentration levels studied, there were no statistically significant differences between the results obtained.

\section{CONCLUSIONS}

The methods developed for the determination of folic acid in pharmaceutical formulations were shown to be simple, selective, and robust in terms of stability and the effects of different brands of sodium hydroxide

TABLE III - Intra-day and inter-day precisions for the proposed methods

\begin{tabular}{|c|c|c|c|c|c|}
\hline \multirow[b]{2}{*}{ Formulation } & \multirow{2}{*}{$\begin{array}{l}\text { Method } \\
(\lambda, \mathrm{nm})\end{array}$} & \multirow{2}{*}{$\begin{array}{c}\text { Concentration } \\
\text { level } \\
\left(\mathrm{mg} \mathrm{L}^{-1}\right)\end{array}$} & \multicolumn{2}{|c|}{ Intra-day precision } & \multirow{2}{*}{$\begin{array}{c}\text { Inter-day precision } \\
\text { RSD } \\
(\%)\end{array}$} \\
\hline & & & $\begin{array}{l}\text { RSD } \\
(\%)\end{array}$ & $\begin{array}{l}\text { RSD } \\
(\%)\end{array}$ & \\
\hline$\overline{\text { Folacin }^{\circledR}}$ & $\mathrm{ZO}$ & 15.0 & 1.3 & 4.7 & 4.1 \\
\hline \multirow[t]{11}{*}{ (solution) } & $(365.5)$ & 25.0 & 1.5 & 1.6 & 1.8 \\
\hline & & 35.0 & 4.3 & 0.4 & 2.7 \\
\hline & D1 & 15.0 & 1.0 & 3.8 & 4.4 \\
\hline & (393.0) & 25.0 & 0.4 & 2.4 & 0.5 \\
\hline & $\Delta \lambda 10$ & 35.0 & 4.0 & 0.9 & 2.4 \\
\hline & D1 & 15.0 & 1.9 & 4.3 & 4.7 \\
\hline & $(393.0)$ & 25.0 & 0.5 & 2.2 & 0.6 \\
\hline & $\Delta \lambda 9$ & 35.0 & 3.4 & 0.8 & 1.1 \\
\hline & D1 & 15.0 & 1.2 & 4.6 & 3.9 \\
\hline & (393.0) & 25.0 & 1.0 & 2.2 & 0.8 \\
\hline & $\Delta \lambda 8$ & 35.0 & 2.5 & 0.8 & 0.3 \\
\hline$\overline{\text { Folacin }^{\circledR}}$ & $\mathrm{ZO}$ & 15.0 & 1.7 & 0.3 & 4.0 \\
\hline \multirow[t]{11}{*}{ (tablet) } & $(255.5)$ & 25.0 & 1.3 & 0.6 & 0.8 \\
\hline & & 35.0 & 1.4 & 0.1 & 1.5 \\
\hline & $\mathrm{ZO}$ & 15.0 & 1.6 & 0.2 & 4.1 \\
\hline & $(283.0)$ & 25.0 & 1.4 & 0.5 & 0.9 \\
\hline & & 35.0 & 1.3 & 0.1 & 1.5 \\
\hline & $\mathrm{ZO}$ & 15.0 & 2.3 & 0.9 & 4.8 \\
\hline & $(365.5)$ & 25.0 & 1.8 & 1.6 & 2.5 \\
\hline & & 35.0 & 1.1 & 0.4 & 2.3 \\
\hline & D1 & 15.0 & 1.5 & 0.6 & 3.8 \\
\hline & (393.0) & 25.0 & 1.3 & 0.7 & 0.2 \\
\hline & $\Delta \lambda 10$ & 35.0 & 1.5 & 0.1 & 0.7 \\
\hline \multirow[t]{12}{*}{ Capsules } & $\mathrm{ZO}$ & 15.0 & 1.4 & 0.9 & 1.4 \\
\hline & $(255.5)$ & 25.0 & 2.5 & 1.4 & 2.6 \\
\hline & & 35.0 & 1.2 & 1.7 & 2.7 \\
\hline & $\mathrm{ZO}$ & 15.0 & 1.2 & 0.7 & 1.4 \\
\hline & (283.0) & 25.0 & 2.4 & 1.5 & 2.6 \\
\hline & & 35.0 & 1.2 & 1.7 & 2.7 \\
\hline & $\mathrm{ZO}$ & 15.0 & 1.8 & 1.5 & 1.3 \\
\hline & $(365.5)$ & 25.0 & 2.6 & 1.1 & 2.5 \\
\hline & & 35.0 & 1.3 & 1.9 & 2.6 \\
\hline & D1 & 15.0 & 1.0 & 0.4 & 1.6 \\
\hline & (393.0) & 25.0 & 2.3 & 1.6 & 2.9 \\
\hline & $\Delta \lambda 10$ & 35.0 & 1.1 & 1.4 & 2.6 \\
\hline
\end{tabular}

ZO - Zero order, D1 - First order derivative, RSD - Relative standard deviation. 
and different solvent concentrations. Good linearity was achieved in the concentration range studied, together with satisfactory accuracy and precision. The proposed methods offer an alternative for use in the quality control of pharmaceutical formulations, being less complex and requiring smaller amounts of toxic reagents, compared to HPLC.

\section{ACKNOWLEDGMENTS}

The authors are grateful to CNPq and UFPI for the provision of Master's and undergraduate scholarships, and to Galeno Pharmacies (especially A. K. M. F. Lustosa) for supplying the samples used in this work.

\section{REFERENCES}

AGÊNCIA NACIONAL DE VIGILÂNCIA SANITÁRIA. ANVISA. Resolução no. 899 de 29 de maio de 2003. Determina a publicação do "Guia para validação de métodos analíticos e bioanalíticos”. Diário Oficial da União, Brasília, 02 jun. 2003.

AGÊNCIA NACIONAL DE VIGILÂNCIA SANITÁRIA. ANVISA. Farmacopeia Brasileira. 5. ed. Brasília: Editora FIOCRUZ, 2010.

AURORA-PRADO, M.S.; SILVA, C.A.; TAVARES, M.F.; ALTRIA, K.D. Determination of folic acid in tablets by microemulsion electrokinetic chromatography. $J$. Chromatogr. A, v.1051, n.1, p.291-296, 2004.

BAILEY, L.B. New standard for dietary folate intake in pregnant women. Am. J. Clin. Nutr., v.71, n.5, p.1304-1307, 2000.

BEITOLLAHI, H.; SHEIKHSHOAIE, I. Electrocatalytic and simultaneous determination of isoproterenol, uric acid and folic acid at molybdenum (VI) complex-carbon nanotube paste electrode. Electrochim. Acta, v.56, n.27, p.1025910263, 2011.

CASELUNGHE, M.B.; LINDEBERG, J. Biosensor-based determination of folic acid in fortified food. Food Chem., v.70, n.4, p.523-532, 2000.

CATHARINO, R.R.; GODOY, H.T. Otimização da determinação de ácido fólico em leites enriquecidos através da análise de superfície de resposta. Cienc. Tec. Aliment., v.21, n.3, p.326-329, 2001.
CATHARINO, R.R.; GODOY, H.T.; LIMA-PALLONE, J.A. Metodologia analítica para determinação de folatos e ácido fólico em alimentos. Quím. Nova, v.29, n.5, p.972, 2006.

CATHARINO, R.R.; VISENTAINER, J.V.; GODOY, H.T. Avaliação das condições experimentais de CLAE na determinação de ácido fólico em leites enriquecidos. Cienc. Tec. Aliment., v.23, n.3, p.389-395, 2003.

CHAUDHARY, A.; WANG, J.; PRABHU, S. Development and validation of a high-performance liquid chromatography method for the simultaneous determination of aspirin and folic acid from nano-particulate systems. Biomed. Chromatogr., v.24, n.9, p.919-925, 2010.

COZZOLINO, S.M.F. Biodisponibilidade de nutrientes. 3. ed. Barueri, SP: Manole, 2009.

CRANE, N.T.; WILSON, D.B.; COOK, D.A.; LEWIS, C.J.; YETLEY, E.A.; RADER, J.I. Evaluating food fortification options: general principles revisited with folic acid. Am J. Publ. Health, v.85, n.5, p.660-666, 1995.

CZEIZE, A.E.; DUDAS, I. Prevention of the first occurrence of neural tube defects by perioconceptional vitamin supplementation. New Engl. J. Med., v.327, n.226, p.18321835, 1992.

DECONINCK, E.; CREVITS, S.; BATEN, P.; COURSELLE, P.; DE BEER, J. A validated ultra high pressure liquid chromatographic method for qualification and quantification of folic acid in pharmaceutical preparations. J. Pharmac. Biomed., v.54, n.5, p.995-1000, 2011.

DONATO, E.; CANEDO, N.A.P.; ADAMS, A.I.H.; FROEHLICH, P.E.; BERGOLD, A. Espectrofotometria derivada: uma contribuição prática para o desenvolvimento de métodos. Rev. Ciênc. Farm. Básica Apl., v.31, n.2, p.125130, 2010.

ENSAFI, A.A.; KARIMI-MALEH, H. Modified multiwall carbon nanotubes paste electrode as a sensor for simultaneous determination of 6-thioguanine and folic acid using ferrocenedicarboxylic acid as a mediator. $J$. Electroanal. Chem., v.640, n.1, p.75-83, 2010.

FLORES, J.R.; PENALVO, G.C.; MANSILLA, A.E.; GOMEZ, M.J. Capillary electrophoretic determination of methotrexate, leucovorin and folic acid in human urine. $J$. Chromatogr. B, v.819, n.1, p.141-147, 2005. 
INSTITUTO NACIONAL DE METROLOGIA. INMETRO. Orientações sobre validação de métodos analíticos. DOQCGCRE-008, revisão 04, Jul. 2011.

INTERNATIONAL CONFERENCE ON HARMONIZATION. ICH. Guideline Q7: Good manufacturing practice guide for active pharmaceutical ingredients. [S.1.]: International Conference on Harmonization, 2000.

KRISHNASWAMY, K; NAIR, K.M. Importance of folate in human nutrition. Br. J. Nutr., v.85, n.2, p.115-124, 2001.

MOURA, J.I.; MOITA, G.C. Determinação simultânea de olanzapina e cloridrato de fluoxetina em formulações farmacêuticas por espectrofotometria derivativa. Quím. Nova, v.35, n.3, p.627-633, 2012.

NAGARAJA, P.; VASANTHA, R.A.; YATHIRAJAN, H.S. Spectrophotometric determination of folic acid in pharmaceutical preparations by coupling reactions with iminodibenzyl or 3-aminophenol or sodium molybdatepyrocatechol. Anal. Biochem., v.307, n.2, p.316-321, 2002.

NASSER, C.; NOBRE, C.; MESQUITA, S.; RUIZ, J.G.; CARLOS, H.R.; PROUVOT, L.; YACUBIAN, M.T. Semana da conscientização sobre a importância do ácido fólico. J. Epilepsy Clin. Neurophysiol., v.11, n.4, p.199203, 2005.

NELSON, B.C.; SHARPLESS, K.E.; SANDER, L.C. Quantitative determination of folic acid in multivitamin/ multielement tablets using liquid chromatography/tandem mass spectrometry. J. Chromatogr. A, v.1135, n.2, p.203$211,2006$.

NIE, F.; HE, Y.; LU, J. An investigation of the chemiluminescence reaction in the sodium hypochlorite-folic acid-emicarbazide hydrochloride system. J. Microchem., v.65, n.3, p.319-323, 2000 .

OAKLEY, G.P.; ERICKSON, J.D.; ADAMS, M.J. Urgent need to increase folic acid consumption. J. Am. Med. Assoc., v.274, n.21, p.1717-1718, 1995.

PACHECO, S.S.; BRAGA, C.; SOUZA, A.I.D.; FIGUEIRO, J.N. Effects of folic acid fortification on the prevalence of neural tube defects. Rev. Saúde Públ., v.43, n.4, p.565-571, 2009.
PESCE, M.A.; BODOURIAN, S.H. Evaluation of a fluorescence polarization immunoassay procedure for quantitation of methotrexate. Ther. Drugs Monit., v.8, n.1, p.115, 1986.

PRASAD, B.B.; TIWARI, M.P.; MADHURI, R.; SHARMA, P.S. Development of a highly sensitive and selective hyphenated technique (molecularly imprinted micro-solid phase extraction fiber-molecularly imprinted polymer fiber sensor) for ultratrace analysis of folic acid. Anal. Chim. Acta, v.662, n.1, p.14-22, 2010.

RAO, G.R.; KANJILAL, G.; MOHAN, K.R. Extended application of folin-ciocalteu reagent in the determination of drugs. Analyst, v.103, n.1230, p.993-994, 1978.

RÊGO, J.F.; MOURA, J.I.M.; MOITA, G.C. Determinação de olanzapina em formulações farmacêuticas por espectrofotometria: desenvolvimento e validação. Quim. Nova, v.33, p.1-7, 2010.

SANTOS, L.M.P.; PEREIRA, M.Z. Efeito da fortificação com ácido fólico na redução dos defeitos do tubo neural. $\mathrm{Cad}$. Saúde Públ., v.23, n.1, p.17-24, 2007.

VAZE, V.D.; SRIVASTAVA, A.K. Electrochemical behavior of folic acid at calixarene based chemically modified electrodes and its determination by adsorptive stripping voltammetry. Electrochim. Acta, v.53, n.4, p.1713-1721, 2007.

VIDOTTI, E.C.; ROLLEMBERG, M.C.E. Derivative spectrophotometry: a simple strategy for simultaneous determination of food dyes. Quim. Nova, v.29, n.2, p.230233, 2006.

ZHAO, S.; YUAN, H.; XIE, C.; XIAO, D. Determination of folic acid by capillary electrophoresis with chemiluminescence detection. J. Chromatogr. A, v. 1107, n. 1, p. 290-293, 2006.

ZARE, H.R.; SHISHEHBORE, M.R.; NEMATOLLAHI, D. A highly sensitive and selective sensor on the basis of 4-hydroxy-2-(triphenylphosphonio) phenolate and multiwall carbon nanotubes for electrocatalytic determination of folic acid in presence of ascorbic acid and uric acid. Electrochim. Acta, v.58, p.654-661, 2011.

Received for publication on $06^{\text {th }}$ October 2015 Accepted for publication on $13^{\text {th }}$ September 2016 